\title{
HISTÓRIAS EM QUADRINHOS COMO ESPAÇO PEDAGÓGICO DE LEITURA NA FORMAÇÂO DO LEITOR: CRUZANDO LIMITES ANTES IMPOSSÍVEIS
}

\author{
Ayane Priscila de Araújo Alves \\ Orientanda \\ ayanepriscila05@gmail.com \\ $\operatorname{Prof}^{a}$ Dr $^{a}$ Edna Gomes Pinheiro \\ $D C I-U F P B$ \\ Orientadora \\ ednagomespi@yahoo.com.br
}

Resumo

\begin{abstract}
Enfatiza que por meio da leitura de história em quadrinho (HQs), considerada como fonte de mediação da informação e apropriação do conhecimento, o leitor encontra um espaço ilimitado que propicia uma continua reorganização de ideias e informações. Ressalta, que em um passado recente, os leitores de HQs foram reprimidos e subestimados por gostarem desse tipo de leitura, visto que naquela época, entendia-se ser prejudicial às crianças, visto que essa leitura não se articulava com estudo, nem com a escola, era apenas para quem não tinha nada melhor na vida para fazer. Atualmente, esse discurso mudou, haja vista que a distância entre as HQs e a escola, estreitou, a julgar que elas estão em sala de aula. Contudo, ainda, existem dúvidas e preconceitos entre professores, pais e autoridades de ensino. Aponta que essas considerações serviram como fonte de inspiração para a construção do problema de pesquisa: como as histórias em quadrinhos (HQS) podem contribuir para o desenvolvimento da competência leitora? Traz como objetivo geral, demonstrar a relevância das Histórias em Quadrinhos para a formação leitora dos alunos da alfabetização, turno matinal da Escola Municipal Miguel Alves. Elenca os seguintes objetivos específícos: delinear o porquê da desvalorização das HQs no processo ensino-aprendizagem; Identificar como as HQs circulam no cotidiano da Escola Municipal Miguel Alves, especificamente, na sala de aula, como um recurso relevante para a formação de leitores nas práticas pedagógicas; conhecer como as HQs, vistas em seus aspectos educativos no ato de ler, vem sendo utilizadas e reinventadas com os alunos da alfabetização, turno matinal da Escola Municipal Miguel Alves e; verificar os aspectos didáticos das HQs como recursos relevantes para a formação de leitores. Afirma que para compreender a cientificidade do estudo e apoiar as análises dos dados coletados, buscou respaldo nas ideias de alguns autores, a saber: Chinen (2011); Freire (1987); Moya (1994); Vergueiro (2005) dentre outros. Evidencia que o percurso metodológico está pautado na pesquisa exploratória, bibliográfica de caráter qualitativo. Conclui que as contribuições das histórias em quadrinhos, categorizadas, inicialmente apenas como recreação e passatempo, vêm sendo constantemente analisadas por estudiosos de várias áreas do conhecimento humano. Em destaque aqueles que investigam a HQs como fonte de informação capaz de incentivar o gosto e o prazer de ler, visto que podem ser considerados recursos de apoio pedagógico ao despertar o imaginário e o lúdico, veicular informações e transmitir conhecimento aos leitores.
\end{abstract}

Palavras-chave: Histórias em Quadrinhos. Leitura. Formação de leitores. Gibiteca 